Check for updates

Cite this: RSC Adv., 2019, 9, 4659

Received 20th November 2018 Accepted 31st January 2019

DOI: 10.1039/c8ra09551e

rsc.li/rsc-advances

\title{
A novel highly specific and ultrasensitive fluorescent probe for monitoring hypochlorous acid and its application in live cells $\dagger$
}

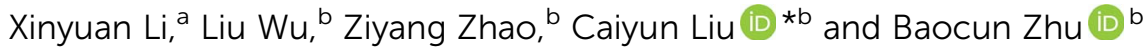

Based on the important role of hypochlorous acid $(\mathrm{HOCl})$ in the immune system and numerous physiological processes, the detection of intracellular basal $\mathrm{HOCl}$ is of significant interest. In this work, we present a simple thiocarbamate-protected fluorescein fluorescent probe, TCFL, for imaging basal $\mathrm{HOCl}$ in live cells. Surprisingly, probe TCFL could determine $\mathrm{HOCl}$ quantitatively in a large concentration range with a detection limit of $0.65 \mathrm{nM}$. In addition, probe TCFL showed excellent specificity for $\mathrm{HOCl}$ in the presence of other higher concentration analytes $(1 \mathrm{mM})$. Moreover, probe TCFL exhibited a rapid response (within 3 s) to $\mathrm{HOCl}$ and thus could provide a tool for real-time monitoring of $\mathrm{HOCl}$. Importantly, probe TCFL with outstanding response features could be applied for monitoring basal $\mathrm{HOCl}$ in live cells.
\end{abstract}

\section{Introduction}

As an important reactive oxygen species (ROS), endogenous $\mathrm{HOCl}$ is generated from the peroxidation of $\mathrm{Cl}^{-}$and $\mathrm{H}_{2} \mathrm{O}_{2}$ assisted by myeloperoxidase in biological systems. ${ }^{1,2}$ Hypochlorous acid at low concentration plays an important role in immune defense and cellular signal transduction in biosystems. ${ }^{3-5}$ However, abnormal production of hypochlorous acid can lead to various health disorders because of the highly reactive characteristics of $\mathrm{HOCl}^{6-8}$ Therefore, the development of a proper tool for tracking basal $\mathrm{HOCl}$ in live cells is essential.

Fluorescent probes have attracted much attention owing to their outstanding sensitivity and unique bioimaging applications in live cells. ${ }^{9-12}$ To date, although many fluorescent probes for $\mathrm{HOCl}$ have been explored, most of them cannot specifically detect intracellular basal HOCl because of their delayed response, and unsatisfactory sensitivity and selectivity. ${ }^{\mathbf{1 3 - 4 5}}$ Additionally, most of the available probes possess poor water solubility, which hinders their bioimaging applications. Therefore, constructing water soluble, highly selective and sensitive fast-response fluorescent probes is of great importance to monitor intracellular basal HOCl levels.

\footnotetext{
${ }^{a}$ Class 15, Grade 2 (64), Laiyang No. 1 High School, Laiyang 265200, P. R. China ${ }^{b}$ School of Resources and Environment, University of Jinan, Shandong Provincial Engineering Technology Research Center for Ecological Carbon Sink and Capture Utilization, Jinan 250022, P. R. China. E-mail: liucaiyun1982072@163.com; Fax: +86-531-82767617; Tel: +86-531-82767617

† Electronic supplementary information (ESI) available. See DOI: 10.1039/c8ra09551e
}

Herein, we present a water soluble thiocarbamate-caged fluorescein fluorescent probe, TCFL, for detecting $\mathrm{HOCl}$ with high selectivity and sensitivity. The TCFL probe exhibited a fast response (within $3 \mathrm{~s}$ ), ultrasensitivity (detection limit $=0.65 \mathrm{nM}$ ) and preeminent specificity for $\mathrm{HOCl}$. Importantly, the bioimaging results indicated that the TCFL probe could achieve specific monitoring of basal HOCl levels in live cells.

\section{Experimental section}

\subsection{Materials and instruments}

All chemicals in this work were obtained commercially and used without further purification. High resolution mass spectra (HRMS) were recorded on a LC-MS 2010A (Shimadzu) instrument. ${ }^{1} \mathrm{H}$ and ${ }^{13} \mathrm{C}$ NMR data were acquired on a Bruker AV-400 NMR spectrometer. Absorption data were measured on a UV3101PC spectrophotometer. Fluorescence data were obtained on a Horiba FluoroMax-4 spectrophotometer. Fluorescence imaging of $\mathrm{HOCl}$ in live RAW 264.7 macrophage cells was performed on a Leica TCS SP5 microscope.

\subsection{Synthesis of probe TCFL}

Dimethylthiocarbamoyl chloride $(1.24 \mathrm{~g}, 10 \mathrm{mmol})$ was slowly added to fluorescein $(332 \mathrm{mg}, 1 \mathrm{mmol})$ in dry $\mathrm{CH}_{2} \mathrm{Cl}_{2}(15 \mathrm{~mL})$ in batches. Subsequently, $N$-diisopropylethylamine $(500 \mu \mathrm{L})$ was slowly added to the reaction mixture in batches. The resulting mixture was stirred at room temperature until the reaction was complete. After removing the solvents by decompression-evaporation, the residues were purified by silica column chromatography $\left(\mathrm{CH}_{2} \mathrm{Cl}_{2}\right.$ as an eluent) to 
achieve pure fluorescent probe TCFL (436 mg, 86\%). ${ }^{1} \mathrm{H}-\mathrm{NMR}$ $\left(400 \mathrm{MHz}, \mathrm{CDCl}_{3}\right) \delta(\mathrm{ppm}): 3.311(\mathrm{~s}, 3 \mathrm{H}), 3.361(\mathrm{~s}, 3 \mathrm{H}), 6.583-$ $6.635(\mathrm{~m}, 2 \mathrm{H}), 6.725(\mathrm{~d}, J=1.6 \mathrm{~Hz}, 1 \mathrm{H}), 6.794(\mathrm{~d}, J=8.8 \mathrm{~Hz}$, $1 \mathrm{H}), 6.855(\mathrm{~d}, J=8.4 \mathrm{~Hz}, 1 \mathrm{H}), 7.161(\mathrm{~d}, J=2.4 \mathrm{~Hz}, 1 \mathrm{H}), 7.333(\mathrm{~d}$, $J=3.6 \mathrm{~Hz}, 1 \mathrm{H}), 7.746(\mathrm{t}, J=7.2 \mathrm{~Hz}, 1 \mathrm{H}), 7.820(\mathrm{t}, J=8.0 \mathrm{~Hz}$, $1 \mathrm{H}), 8.036$ (d, $J=7.6 \mathrm{~Hz}, 1 \mathrm{H}), 10.229$ (s, 1H); ${ }^{13} \mathrm{C}-\mathrm{NMR}(100$ MHz, DMSO- $\left.d_{6}\right) \delta(\mathrm{ppm}): 39.11,43.34,82.57,102.73,109.60$, $111.71,113.54,116.80,119.70,124.52$, 125.29, 126.33, 128.99, 129.60, 130.78, 136.27, 151.43, 152.06, 152.77, 155.44, 160.18, 169.01, 186.05. HRMS (ESI): calcd for $\mathrm{C}_{23} \mathrm{H}_{18} \mathrm{NO}_{5} \mathrm{~S}[\mathrm{M}+\mathrm{H}]^{+}$ 420.0900; found, 420.0906 .

\section{Results and discussion}

\subsection{Design and synthesis of the fluorescent probe TCFL}

Recently, Falck et al. demonstrated that a dimethylthiocarbamate (DMTC) group is a desirable protecting group of hydroxyl moieties, and its cleavage can be realized by means of the oxidation of a sulfide. ${ }^{46}$ Thus, we reasonably envisioned that the DMTC moiety might be a preferred recognition receptor of HOCl with strong oxidation capabilities. Fluorescein, as a commercially available dye, has been successfully used in the development of different fluorescent probes for monitoring various bioactive molecules in biosystems owing to its excellent photophysical properties. ${ }^{47-49}$ Additionally, modification of the hydroxyl moiety results in a spironolactone structure with suppressed fluorescence. ${ }^{50-52}$ Therefore, we deemed that DMTC-caged fluorescein with reduced fluorescence could once again exhibit enhanced fluorescence by means of the removal of DMTC, induced by the oxidation of HOCl. Bearing the above-mentioned considerations in mind, we synthesized DMTC-caged fluorescein as highly selective fluorescent probe TCFL for detecting $\mathrm{HOCl}$ with excellent sensitivity (Scheme 1).

\subsection{The determination of HOCl by probe TCFL}

Because probe TCFL possesses ideal water solubility, the fluorescence spectra of probe TCFL for detection of $\mathrm{HOCl}$ were evaluated in a buffered aqueous solution (pH 7.4, PBS 5 mM). As shown in Fig. 1, the free probe TCFL exhibited faint fluorescence. Surprisingly, an ultrafast (within 3 s) and enormous fluorescence enhancement at $515 \mathrm{~nm}$ was observed in the presence of HOCl. This feature suggested that probe TCFL has potential for real-time and ultrasensitive detection of $\mathrm{HOCl}$ in the environment and biological systems.

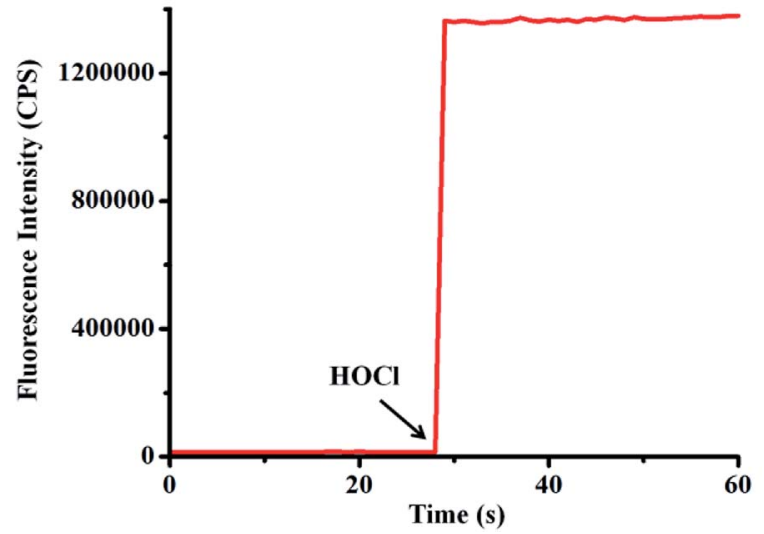

Fig. 1 Time-course of probe TCFL $(5 \mu \mathrm{M})$ for monitoring $\mathrm{HOCl}(8 \mu \mathrm{M})$ in PBS solution ( $5 \mathrm{mM}, \mathrm{pH}=7.4$ ) at $25^{\circ} \mathrm{C}$. $\lambda_{\mathrm{ex}}=470 \mathrm{~nm}, \lambda_{\mathrm{em}}=515 \mathrm{~nm}$. Slit widths: $W_{\mathrm{ex}}=W_{\mathrm{em}}=1 \mathrm{~nm}$.

Additionally, the fluorescence intensity at $515 \mathrm{~nm}$ was enhanced gradually with an increasing amount of $\mathrm{HOCl}$ (Fig. 2a). The fluorescence intensity at $515 \mathrm{~nm}$ showed a satisfactory linear relationship with the concentration of HOCl ranging from 1-8 $\mu \mathrm{M}$ (linear equation: $y=200470 \times$ [HOCl] $\left.(\mu \mathrm{M})-91102, R^{2}=0.9988\right)$ (Fig. 2b). Moreover, to examine the feasibility of using probe TCFL to measure extremely low levels of $\mathrm{HOCl}$, the titration of $\mathrm{HOCl}$ at ultralow concentrations was carefully carried out. Satisfactorily, a good linear relationship between the fluorescence intensity at $515 \mathrm{~nm}$ and the $\mathrm{HOCl}$ concentration ranging from 0-30 nM was successfully obtained, which indicated that probe TCFL could accurately detect $\mathrm{HOCl}$ at the nanomolar level (Fig. 2c). Furthermore, the detection limit (DL) was calculated to be $0.65 \mathrm{nM}(3 \sigma / k)$. Consequently, we envisioned that TCFL would be capable of tracking the basal HOCl levels in live cells without exogenous stimuli.

Next, the absorption spectra of probe TCFL in the presence of $\mathrm{HOCl}$ were recorded. The absorption spectra at around $490 \mathrm{~nm}$ generally increased with the gradual addition of $\mathrm{HOCl}$ (0-8 $\mu \mathrm{M})$ (Fig. 3a). Additionally, the absorbance of probe TCFL at $490 \mathrm{~nm}$ was linearly proportional $\left(R^{2}=0.9971\right)$ to the concentration of HOCl ranging from $0-8 \mu \mathrm{M}$ (Fig. 3b). These data indicated that probe TCFL could accurately detect $\mathrm{HOCl}$ with satisfactory sensitivity using the absorption spectrum method.

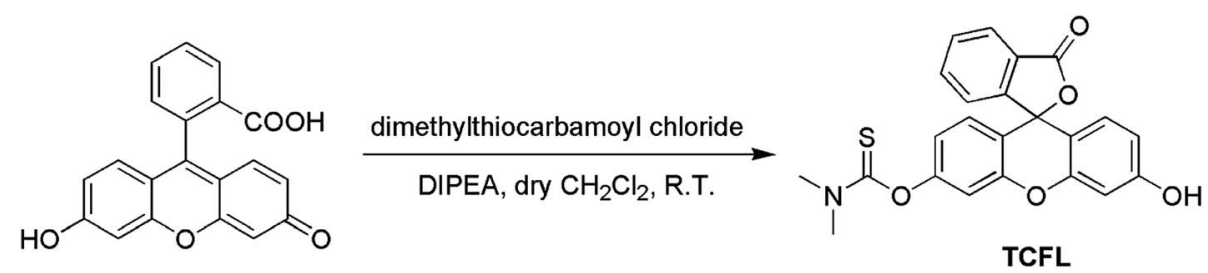

Scheme 1 The synthesis of the fluorescent probe TCFL. 

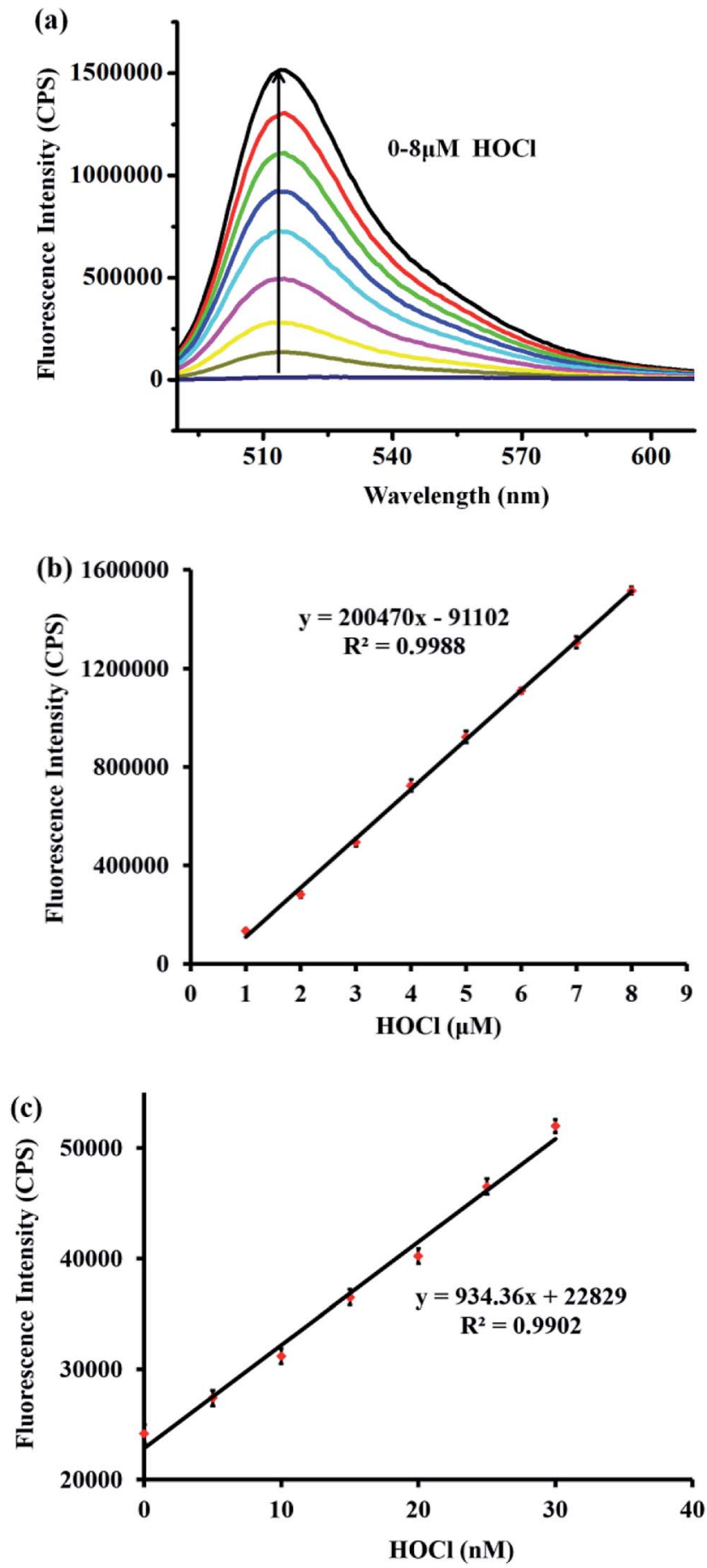

Fig. 2 (a) The fluorescence spectra of probe TCFL $(5 \mu \mathrm{M})$ with increasing concentration of $\mathrm{HOCl}(0-8 \mu \mathrm{M})$ in $\mathrm{PBS}$ solution $(5 \mathrm{mM}, \mathrm{pH}$ =7.4). (b) The fluorescence intensity at $515 \mathrm{~nm}$ of probe TCFL $(5 \mu \mathrm{M})$ as a function of $\mathrm{HOCl}$ concentration $(1-8 \mu \mathrm{M}) . \lambda_{\mathrm{ex}}=470 \mathrm{~nm}$. Slit widths: $W_{\mathrm{ex}}=W_{\mathrm{em}}=1 \mathrm{~nm}$. (c) The fluorescence intensity at $515 \mathrm{~nm}$ of probe TCFL $(1 \mu \mathrm{M})$ as a function of $\mathrm{HOCl}$ concentration $(0-30 \mathrm{nM}) \cdot \lambda_{\text {ex }}=$ $470 \mathrm{~nm}$. Slit widths: $W_{\mathrm{ex}}=1 \mathrm{~nm}, W_{\mathrm{em}}=2 \mathrm{~nm}$. Each spectrum was recorded $1 \mathrm{~min}$ after $\mathrm{HOCl}$ addition at $25^{\circ} \mathrm{C}$. Error bar $=\operatorname{RSD}(n=3)$.

\subsection{Specificity of probe TCFL for detecting $\mathrm{HOCl}$}

Next, we studied the specificity of probe TCFL for measuring HOCl. As expected, compared with $\mathrm{HOCl}$, various other substances including $\mathrm{K}^{+}, \mathrm{Ca}^{2+}, \mathrm{Mg}^{2+}, \mathrm{Na}^{+}, \mathrm{Zn}^{2+}, \mathrm{Al}^{3+}, \mathrm{NO}_{3}^{-}$,
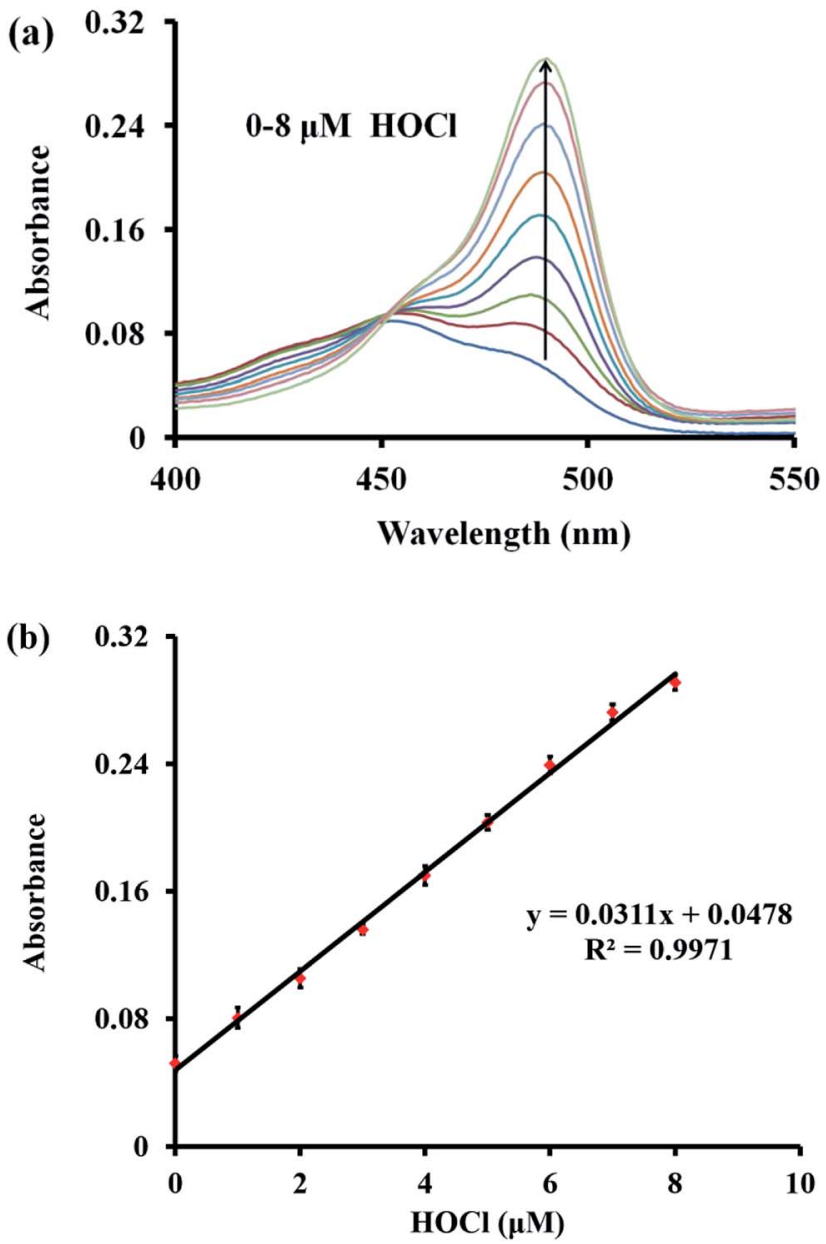

Fig. 3 (a) Absorption responses of probe TCFL $(5 \mu \mathrm{M})$ in the presence of different concentrations of $\mathrm{HOCl}(0-8 \mu \mathrm{M})$ in PBS solution $(5 \mathrm{mM}$, $\mathrm{pH}=7.4$ ). (b) The absorbance of TCFL at $490 \mathrm{~nm}$ as a function of $\mathrm{HOCl}$ concentration $(0-8 \mu \mathrm{M})$. Each spectrum was recorded $1 \mathrm{~min}$ after $\mathrm{HOCl}$ addition at $25^{\circ} \mathrm{C}$. Error bar $=\mathrm{RSD}(n=3)$.

$\mathrm{NO}_{2}{ }^{-}, \mathrm{Cu}^{2+}, \mathrm{Fe}^{3+}, \mathrm{Fe}^{2+}$, cysteine (Cys), $\mathrm{H}_{2} \mathrm{O}_{2}$, tert-butylhydroperoxide (TBHP), hydroxyl radical $(\cdot \mathrm{OH})$, tert-butoxy radical $\left(\cdot \mathrm{O}^{t} \mathrm{Bu}\right), \mathrm{NO},{ }^{1} \mathrm{O}_{2}, \mathrm{O}_{2}{ }^{-}$, glutathione (GSH), and $\mathrm{ONOO}^{-}$ at a higher concentration $(1 \mathrm{mM})$ resulted in no significant change in fluorescence intensity at $515 \mathrm{~nm}$, indicating that probe TCFL displays the excellent specificity toward $\mathrm{HOCl}$ (Fig. 4). The preeminent selectivity of probe TCFL for monitoring $\mathrm{HOCl}$ can be attributed to the distinctive DMTC recognition receptor.

\subsection{Sensing mechanism of probe TCFL for detecting HOCl}

To uncover the recognition mechanism of probe TCFL with $\mathrm{HOCl}$, a reaction mixture of probe TCFL and HOCl was carefully analyzed by HRMS. When $\mathrm{HOCl}$ was added, the mass peak of probe TCFL $\left(\mathrm{m} / \mathrm{z} 420.0906[\mathrm{M}+\mathrm{H}]^{+}\right)$disappeared, and a new mass peak at $m / z 333.0756$ was discovered, which indicated the production of fluorescein (calcd $\mathrm{m} / \mathrm{z} 333.0757[\mathrm{M}+$ $\mathrm{H}]^{+}$). Based on the published results, ${ }^{45,46}$ a plausible reaction mechanism of probe TCFL for detecting $\mathrm{HOCl}$ is presented in Scheme 2. 


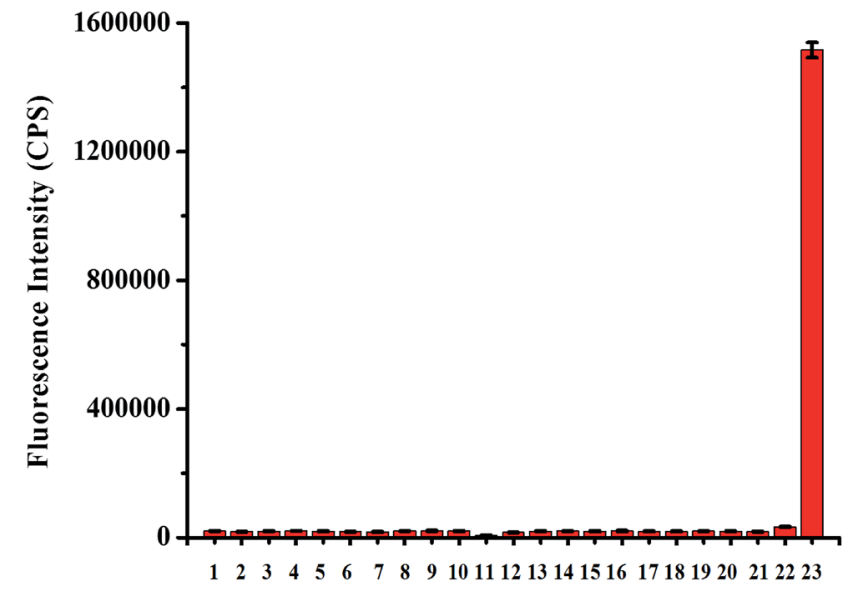

Fig. 4 The fluorescence response of probe TCFL $(5 \mu \mathrm{M})$ in the presence of various analytes ( $1 \mathrm{mM}$ except for $8 \mu \mathrm{M} \mathrm{HOCl}$ ) in PBS solution (5 mM, pH = 7.4). 1. Blank; 2. $\mathrm{K}^{+} ; 3 . \mathrm{Ca}^{2+} ; 4 . \mathrm{Mg}^{2+} ; 5 . \mathrm{Na}^{+} ; 6 . \mathrm{Zn}^{2+} ; 7$. $\mathrm{Al}^{3+} ; 8 . \mathrm{NO}_{3}^{-} ; 9 . \mathrm{NO}_{2}^{-} ; 10 . \mathrm{Cu}^{2+} ; 11 . \mathrm{Fe}^{3+} ; 12 . \mathrm{Fe}^{2+} ; 13 . \mathrm{Cys} ; 14 . \mathrm{H}_{2} \mathrm{O}_{2}$; 15. TBHP; 16. $\mathrm{OH} ; 17 . \cdot \mathrm{O}^{t} \mathrm{Bu} ; 18 . \mathrm{NO} ; 19 .{ }^{1} \mathrm{O}_{2} ; 20 . \mathrm{O}_{2}{ }^{-} ; 21 . \mathrm{GSH} ; 22$. $\mathrm{ONOO}^{-} ; 23$. $\mathrm{HOCl}$. The bars represent the fluorescence intensities at $515 \mathrm{~nm}$ and each spectrum was acquired $1 \mathrm{~min}$ after the addition of each analyte at $25^{\circ} \mathrm{C}$. Error bar $=\operatorname{RSD}(n=3)$.

\subsection{Bioimaging applications of probe TCFL}

Firstly, according to 3-(4,5-dimethylthiazol-2-yl)-2,5diphenyltetrazolium bromide (MTT) tests, the cytotoxicity of probe TCFL was studied in live RAW 264.7 macrophage cells. As illustrated in Fig. 5, probe TCFL exhibits low cytotoxicity. Then, probe TCFL was applied to monitor $\mathrm{HOCl}$ in live RAW 264.7 macrophage cells. After incubation with the TCFL probe $(10 \mu \mathrm{M})$ for $30 \mathrm{~min}$, the cells showed a medium green fluorescence (Fig. 6a and b), indicating that probe

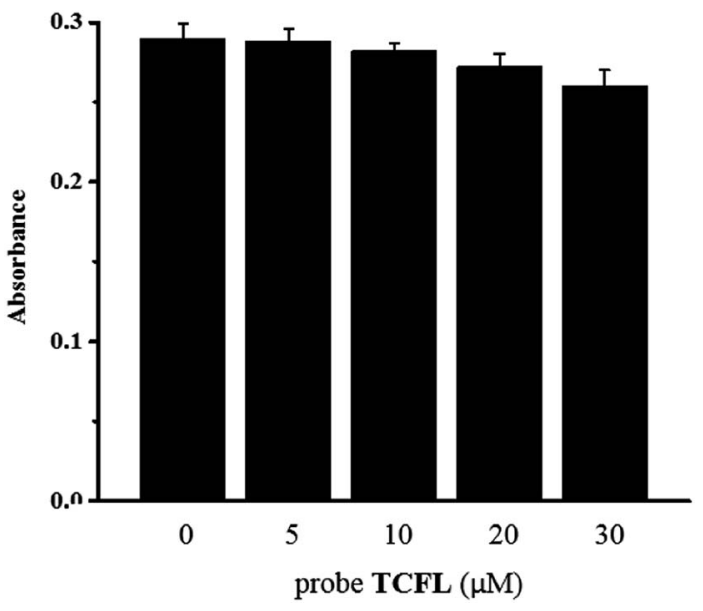

Fig. 5 Cytotoxicity tests of probe TCFL at different concentrations in RAW 264.7 macrophage cells.

TCFL was sensitive enough as a tool to monitor the basal HOCl levels in live cells without stimulation. The application of probe TCFL for the detection of exogenous HOCl was further performed (Fig. 6c and d). Additionally, cells pretreated with PMA (a ROS stimulant) exhibited a relatively brighter fluorescence (Fig. 6e and f). Then, the hypochlorous acid in the cells was scavenged by NAC, and the cells displayed a dramatic reduction in fluorescence (Fig. $6 \mathrm{~g}$ and $\mathrm{h}$ ). These data demonstrated that probe TCFL could monitor the changes in endogenous/exogenous HOCl levels in live cells (Fig. 6i), which is very meaningful to unravel the physiological and pathological functions of HOCl. These results fully confirmed that our proposed probe TCFL can act as a robust tool for imaging basal HOCl and the fluctuations of endogenous/exogenous HOCl levels in live cells.

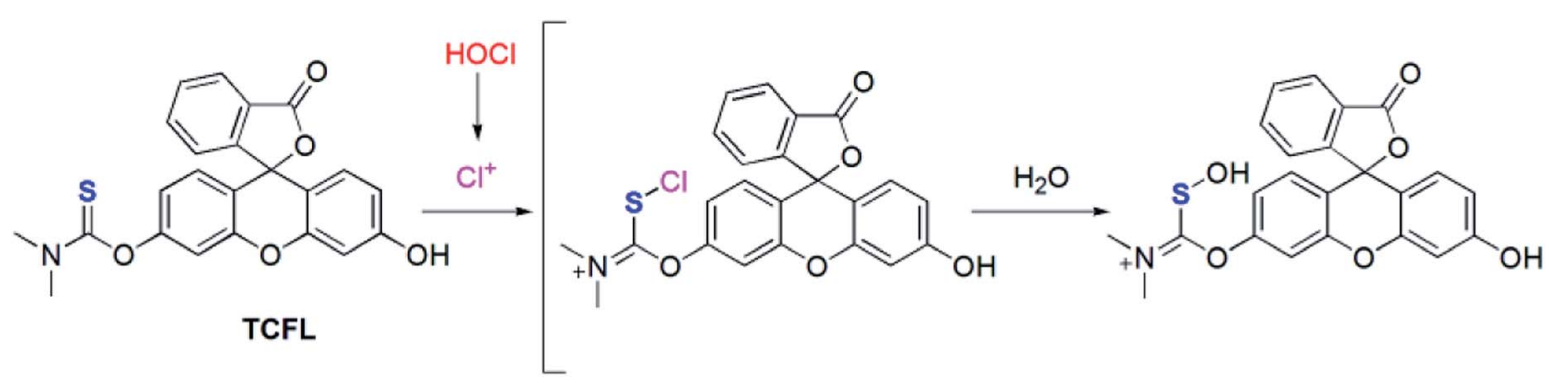

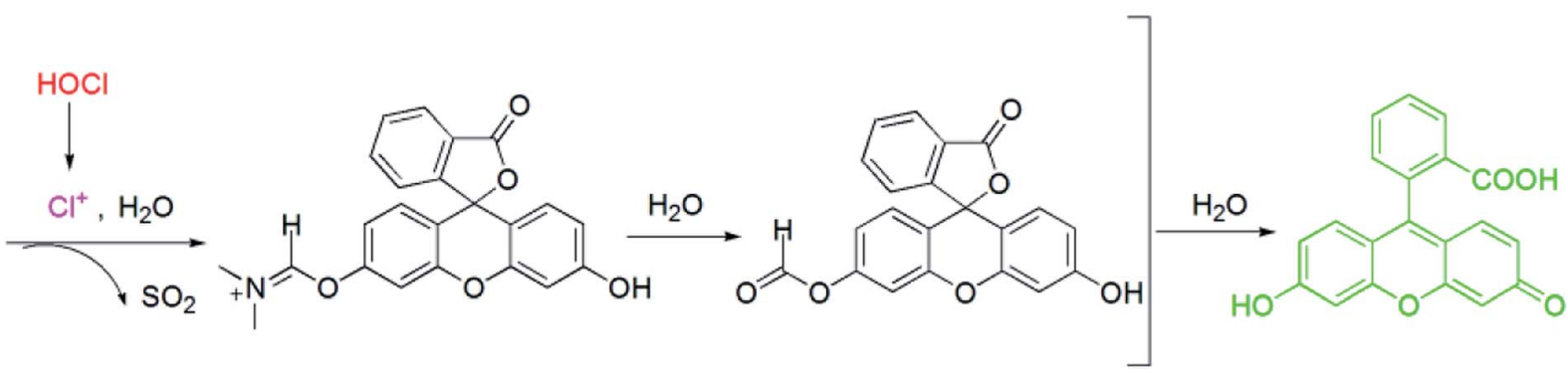

Scheme 2 The response mechanism of the fluorescent probe TCFL for monitoring $\mathrm{HOCl}$. 

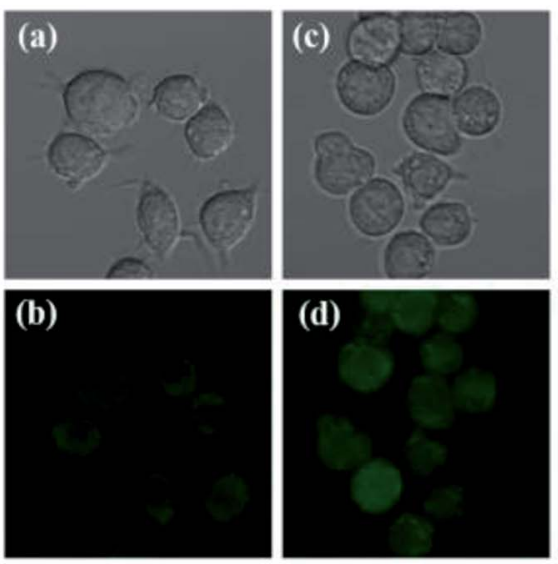
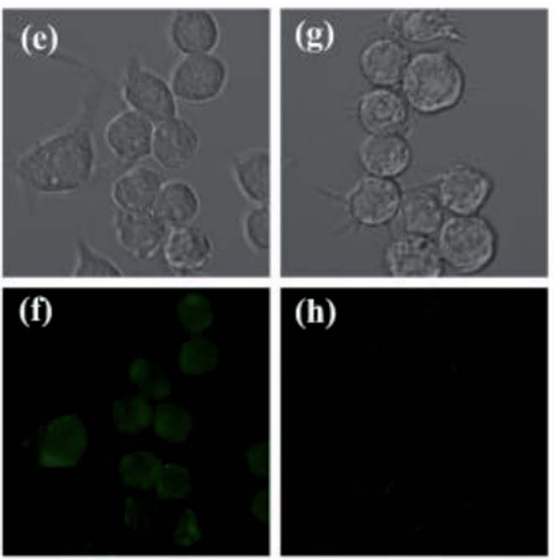

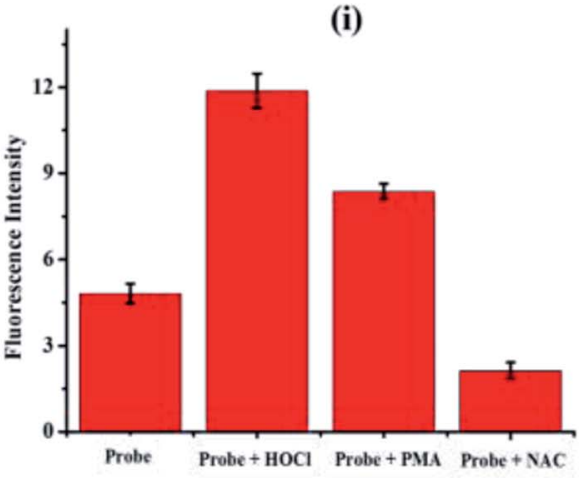

Fig. 6 Fluorescence imaging of $\mathrm{HOCl}$ in live RAW 264.7 macrophage cells: (a and b) the cells loaded with probe TCFL (10 $\mu$ M) for 30 min; (c and d) the cells incubated with probe TCFL $(10 \mu \mathrm{M})$ for $30 \mathrm{~min}$ followed by the addition of $\mathrm{HOCl}(20 \mu \mathrm{M})$ for 10 min; (e and f) the cells loaded with probe TCFL $(10 \mu \mathrm{M})$ for another 30 min after preincubation with $2.0 \mu \mathrm{g} \mathrm{mL}{ }^{-1}$ PMA for $60 \mathrm{~min}$; ( $\mathrm{g}$ and $\mathrm{h}$ ) the cells loaded with probe TCFL (10 $\mu$ M) for another $30 \mathrm{~min}$ after preincubation with $500 \mu \mathrm{M} \mathrm{NAC}$ for $60 \mathrm{~min}$. (i) The bars represent the fluorescence intensities of the corresponding cells. The provided images of live RAW 264.7 macrophages are representative ones ( $n=10$ fields of cells).

\section{Conclusions}

In summary, an efficient DMTC-based specific fluorescent probe, TCFL, with excellent water solubility and ultra-sensitivity for monitoring $\mathrm{HOCl}$ in live cells has been designed. Probe TCFL can realize quantitative detection of $\mathrm{HOCl}$ from 0-30 nM. Moreover, probe TCFL exhibits noteworthy selectivity for $\mathrm{HOCl}$ over other biologically relevant species, which was attributed to the contribution of the unique DMTC recognition receptor. In particular, fluorescence imaging demonstrated that probe TCFL could be effectively applied in imaging basal HOCl levels in live cells. In brief, this highly specific and ultrasensitive fluorescent probe will provide a remarkable tool to track the HOCl levels in aqueous environments and biological systems.

\section{Conflicts of interest}

There are no conflicts of interest to declare.

\section{Acknowledgements}

We gratefully acknowledge financial support from the National Natural Science Foundation of China (21607053 and 21777053), the Shandong Provincial Natural Science Foundation (ZR2017MB014), and the Shandong Province Higher Educational Science and Technology Program (J16LD01).

\section{References}

1 M. A. Shannon, P. W. Bohn, M. Elimelech, J. G. Georgiadis, B. J. Mariñas and A. M. Mayes, Nature, 2008, 452, 301-310.

2 J. Zhang and X. R. Yang, Analyst, 2013, 138, 434-437.

3 Y. W. Yap, M. Whiteman and N. S. Cheung, Cell. Signalling, 2007, 19, 219-228.

4 J. M. Pullar, M. C. M. Vissers and C. C. Winterbourn, IUBMB Life, 2000, 50, 259-266.
5 J. Zhou, L. Li, W. Shi, X. Gao, X. Li and H. Ma, Chem. Sci., 2015, 6, 4884-4888.

6 S. M. Wu and S. V. Pizzo, Arch. Biochem. Biophys., 2001, 391, 119-126.

7 B. C. Dickinson, D. Srikun and C. J. Chang, Curr. Opin. Chem. Biol., 2010, 14, 50-56.

8 K. Li, J. Hou, J. Yang and X. Yu, Chem. Commun., 2017, 53, 5539-5541.

9 B. C. Zhu, Z. K. Wang, Z. Y. Zhao, W. Shu, M. Zhang, L. Wu, C. Y. Liu, Q. X. Duan and P. Jia, Sens. Actuators, B, 2018, 262, 380-385.

10 Q. X. Duan, H. C. Zhu, C. Y. Liu, R. F. Yuan, Z. T. Fang, Z. K. Wang, P. Jia, Z. L. Li, W. L. Sheng and B. C. Zhu, Analyst, 2019, 144, DOI: 10.1039/c8an01696h.

11 Z. Wang, L. Wu, Y. Wang, M. Zhang, Z. Zhao, C. Liu, Q. Duan, P. Jia and B. Zhu, Anal. Chim. Acta, 2019, 1049, 219-225.

12 Q. Duan, X. Lv, C. Liu, Z. Geng, F. Zhang, W. Sheng, Z. Wang, P. Jia, Z. Li, H. Zhu and B. Zhu, Ind. Eng. Chem. Res., 2019, 58, 11-17.

13 Y. Yue, F. Huo, C. Yin, J. O. Escobedo and R. M. Strongin, Analyst, 2016, 141, 1859-1873.

14 X. Q. Chen, X. C. Wang, S. J. Wang, W. Shi, K. Wang and H. M. Ma, Chem.-Eur. J., 2008, 14, 4719-4727.

15 Y. Koide, Y. Urano, K. Hanaoka, T. Terai and T. Nagano, J. Am. Chem. Soc., 2011, 133, 5680-5682.

16 L. Yuan, W. Y. Lin, Y. T. Yang and H. Chen, J. Am. Chem. Soc., 2012, 134, 1200-1211.

17 B. Zhu, L. Wu, M. Zhang, Y. Wang, C. Liu, Z. Wang, Q. Duan and P. Jia, Biosens. Bioelectron., 2018, 107, 218-223.

18 G. H. Cheng, J. L. Fan, W. Sun, K. Sui, X. Jin, J. Y. Wang and X. J. Peng, Analyst, 2013, 138, 6091-6096.

19 Q. X. Duan, P. Jia, Z. H. Zhuang, C. Y. Liu, X. Zhang, Z. K. Wang, W. L. Sheng, Z. L. Li, H. C. Zhu, B. C. Zhu and X. L. Zhang, Anal. Chem., 2019, 91, DOI: 10.1021/ acs.analchem.8b04726. 
20 J. Hou, K. Li, J. Yang, K. Yu, Y. Liao, Y. Ran, Y. Liu, X. Zhou and X. Yu, Chem. Commun., 2015, 51, 6781-6784.

21 Q. Xu, C. H. Heo, G. Kim, H. W. Lee, H. M. Kim and J. Yoon, Angew. Chem., Int. Ed., 2015, 54, 4890-4894.

22 H. Zhu, J. Fan, J. Wang, H. Mu and X. Peng, J. Am. Chem. Soc., 2014, 136, 12820-12823.

23 G. Cheng, J. Fan, W. Sun, J. Cao, C. Hu and X. Peng, Chem. Commun., 2014, 50, 1018-1020.

24 Q. Xu, K.-A. Lee, S. Lee, K. M. Lee, W.-J. Lee and J. Yoon, J. Am. Chem. Soc., 2013, 135, 9944-9949.

25 W. Zhang, W. Liu, P. Li, J. kang, J. Wang, H. Wang and B. Tang, Chem. Commun., 2015, 51, 10150-10152.

26 J. J. Hu, N. Wong, M. Lu, X. Chen, S. Ye, A. Q. Zhao, P. Gao, R. Y. Kao, J. Shen and D. Yang, Chem. Sci., 2016, 7, 20942099.

27 Q. Xu, C. H. Heo, J. A. Kim, H. S. Lee, Y. Hu, D. Kim, K. M. K. Swamy, G. Kim, S. Nam, H. M. Kim and J. Yoon, Anal. Chem., 2016, 88, 6615-6620.

28 P. Jia, Z. Zhuang, C. Liu, Z. Wang, Q. Duan, Z. Liu, H. Zhu, B. Du, B. Zhu, W. Sheng and B. Kang, Anal. Chim. Acta, 2019, DOI: 10.1016/j.aca.2018.11.031.

29 S.-L. Shen, X. Zhao, X.-F. Zhang, X.-L. Liu, H. Wang, Y.-Y. Dai, J.-Y. Miao and B.-X. Zhao, J. Mater. Chem. B, 2017, 5, 289-295.

30 Y. Yang, F. Huo, C. Yin, M. Xu, Y. Hu, J. Chao, Y. Zhang, T. E. Glass and J. Yoon, J. Mater. Chem. B, 2016, 4, 5101-5104.

31 B. Zhu, L. Wu, M. Zhang, Z. Zhao, Z. Wang, Q. Duan, P. Jia, Z. Li, H. Zhu and C. Liu, Sens. Actuators, B, 2018, 267, 589596.

32 B. Shen, Y. Qian, Z. Qi, C. Lu, Q. Sun, X. Xia and Y. Cui, J. Mater. Chem. B, 2017, 5, 5854-5861.

33 X. Liu, Z. Tang, B. Song, H. Ma and J. Yuan, J. Mater. Chem. B, 2017, 5, 2849-2855.

34 J. Xu, H. Yuan, C. Qin, L. Zeng and G. Bao, RSC Adv., 2016, 6, 107525-107532.

35 B. C. Zhu, L. Wu, H. C. Zhu, Z. K. Wang, Q. X. Duan, Z. T. Fang, P. Jia and Z. L. Li, Sens. Actuators, B, 2018, 269, 1-7.
36 Q. Zhang, N. Zhang, Y. Long, X. Qian and Y. Yang, Bioconjugate Chem., 2016, 27, 341-353.

37 P. Chen, Z. Zheng, Y. Zhu, Y. Dong, F. Wang and G. Liang, Anal. Chem., 2017, 89, 5693-5696.

38 Q. Xu, C. H. Heo, J. A. Kim, H. S. Lee, Y. Hu, D. Kim, K. M. K. Swamy, G. Kim, S. Nam, H. M. Kim and J. Yoon, Anal. Chem., 2016, 88, 6615-6620.

39 B. Zhu, L. Wu, M. Zhang, Y. Wang, Z. Zhao, Z. Wang, Q. Duan, P. Jia and C. Liu, Sens. Actuators, B, 2018, 263, 103-108.

40 J. Lv, F. Wang, T. Wei and X. Chen, Ind. Eng. Chem. Res., 2017, 56, 3757-3764.

41 L. Yuan, L. Wang, B. K. Agrawalla, S. J. Park, H. Zhu, B. Sivaraman, J. Peng, Q. H. Xu and Y. T. Chang, J. Am. Chem. Soc., 2015, 137, 5930-5938.

42 K. Xiong, F. Huo, C. Yin, Y. Chu, Y. Yang, J. Chao and A. Zheng, Sens. Actuators, B, 2016, 224, 307-314.

43 H. D. Xiao, K. Xin, H. F. Dou, G. Yin, Y. W. Quan and R. Y. Wang, Chem. Commun., 2015, 51, 1442-1445.

44 Y. Wang, L. Wu, C. Liu, B. Guo, B. Zhu, Z. Wang, Q. Duan, Z. Ma and X. Zhang, J. Mater. Chem. B, 2017, 5, 3377-3382.

45 B. Zhu, P. Li, W. Shu, X. Wang, C. Liu, Y. Wang, Z. Wang, Y. Wang and B. Tang, Anal. Chem., 2016, 88, 12532-12538.

46 D. K. Barma, A. Bandyopadhyay, J. H. Capdevila and J. R. Falck, Org. Lett., 2003, 5, 4755-4757.

47 B. Zhu, Y. Zhao, Q. Zhou, B. Zhang, L. Liu, B. Du and X. Zhang, Eur. J. Org. Chem., 2013, 2013, 888-893.

48 Z. Zhan, R. Liu, L. Chai, Q. Li, K. Zhang and Y. Lv, Anal. Chem., 2017, 89, 9544-9551.

49 Y. Urano, M. Kamiya, K. Kanda, T. Ueno, K. Hirose and T. Nagano, J. Am. Chem. Soc., 2005, 127, 4888-4894.

50 W. Feng, D. Liu, S. Feng and G. Feng, Anal. Chem., 2016, 88, 10648-10653.

51 S. Feng, D. Liu, W. Feng and G. Feng, Anal. Chem., 2017, 89, 3754-3760.

52 X. Jin, S. Wu, M. She, Y. Jia, L. Hao, B. Yin, L. Wang, M. Obst, Y. Shen, Y. Zhang and J. Li, Anal. Chem., 2016, 88, 1125311260. 